\title{
Engineering the Solid Oxide Fuel Cell Electrocatalyst Infiltration Technique for Industrial Use
}

\author{
Regis P. Dowd Jr. ${ }^{\mathrm{a}, \mathrm{Z}}$, Shiwoo Lee ${ }^{\mathrm{b}, \mathrm{c}}$, Yueying Fan ${ }^{\mathrm{b}, \mathrm{c}}$, and Kirk Gerdes ${ }^{\mathrm{b}}$ \\ ${ }^{a}$ Department of Chemical and Petroleum Engineering \\ The University of Kansas, Lawrence, KS 66045, USA \\ ${ }^{\mathrm{b}}$ United States Department of Energy \\ National Energy Technology Laboratory, Morgantown, WV 26507, USA \\ ${ }^{\mathrm{c}}$ AECOM \\ National Energy Technology Laboratory, Morgantown, WV 26507, USA
}

Submitted as

A Technical Paper

To

The International Journal of Hydrogen Energy

$1^{\text {st }}$ submission: April 1, 2016

Recommended for Section/Category: Fuel Cells \& Applications

Key words: Solid Oxide Fuel Cell (SOFC), Electrocatalyst, Infiltration

${ }^{\mathrm{Z}}$ Corresponding E-mail: RegisDowdJr@gmail.com

Telephone: (352)514-5579

Address: 1530 W. $15^{\text {th }}$, Lawrence, KS, 66045 


\begin{abstract}
In this work, we explore various parameters for infiltrating $\mathrm{La}_{0.6} \mathrm{Sr}_{0.4} \mathrm{CoO}_{3-\delta}$ (LSCo) into the $\mathrm{La}_{0.6} \mathrm{Sr}_{0.4} \mathrm{Co}_{0.2} \mathrm{Fe}_{0.8} \mathrm{O}_{3-\delta}(\mathrm{LSCF})-\mathrm{Ce}_{0.8} \mathrm{Sm}_{0.2} \mathrm{O}_{2}$ (SDC) cathode of a planar solid oxide fuel cell (SOFC) using an automated solution dispensing technique for commercial deployment of infiltrated SOFCs by industry. Substrate temperature, chelating agent concentration, and surfactant type were explored to develop a 1-step infiltration process for delivering 8-10 weight percent of LSCo electrocatalyst to the cathode active layer. The results confirm increased fuel cell performance and durability by optimizing the infiltrate solution for increased transport into the cathode's microstructure.
\end{abstract}

\title{
Introduction
}

Solid oxide fuel cells (SOFCs) have great potential in electrical energy generation due to their high-energy conversion efficiency and low greenhouse gas emissions. The elevated exhaust temperatures of SOFCs make them prime candidates for combined heat and power (CHP) applications. Additionally, a SOFC can be combined with a steam or gas turbine, known as a bottoming cycle, to provide very efficient power generation (1). For example, Bicer et al. proposed a novel system to produce syngas from underground coal without mining to generate electricity from an integrated gasification combined cycle and SOFC (2). If the DOE/SECA cost targets are reached, Siefert et al. showed that a SOFC coupled to an anaerobic digester would be an economical way of producing electricity from biogas (3).

SOFC performance, long-term stability, and cost are critical to the successful application of fuel cells in the electric power industry. Infiltration, also known as wet impregnation, is one method that has been used to produce electrodes with high electrocatalytic activity and 
stability by depositing nano-sized particles into the electrode structure (4-9). Lee et al. previously showed that cathode infiltration can reduce polarization resistances of baseline cells with no measurable negative effect on stability $(10,11)$. They confirmed that infiltrated electrocatalysts play an important role in the reduction of oxygen molecules and adsorption of oxygen atoms in the cathode catalyst layer (12).

Currently, the wet impregnation infiltration process for the cathode requires multiple iterations using a low electrocatalyst concentration in order to prevent agglomeration at the cathode's surface while also depositing a sufficient amount of electrocatalyst at the cathode active layer to positively impact performance and degradation (13-15). Li et al. established a one step infiltration method by submerging a tubular fuel cell into an electrocatalyst and then heating the solution (13). Others have demonstrated how SDC and $\mathrm{La}_{0.80} \mathrm{Sr}_{0.20} \mathrm{MnO}_{3-\delta}$ (LSM) infiltration enhance the performance of tubular SOFCs (16-18). Additionally, Zhou et al. infiltrated planar SOFCs by using a vacuum dip-coating method (19). In these approaches, the electrocatalyst cannot be tailored for the anode and cathode independently. Moreover, these processes require additional energy input in the form of heat and vacuum, which makes it more challenging for integration into an existing manufacturing process. Chen et al. demonstrated that a single step wet infiltration process is able to deliver sufficient LSM electrocatalyst into a bismuth oxide porous backbone in order to increase performance and durability (20). It is highly desired to determine the optimal conditions for wet impregnation infiltration in order to shorten the manufacturing process to a single step, thereby greatly reducing the overall time and cost.

The key variables for optimizing the wet infiltration process include surfactant type and concentration, chelating agent type and concentration, substrate temperature, $\mathrm{pH}$ level, and 
electrocatalyst infiltrate concentration. Godinez et al. previously studied the effect of different surfactants and $\mathrm{pH}$ levels on the transport of nanoparticles in saturated porous media (21). Godinez et al. found that transport of nanoparticles in saturated porous media was highly dependent on the type of surfactant added to the solution (21). Additionally, Zhu et al. studied the effect of various surfactants, chelating agents, and $\mathrm{pH}$ on SOFC performance (22). Starov et al. found that mean pore size in porous media plays a critical role on the effect of surfactant concentration on permeability of the porous media (23). Depending on the mean pore size, surfactants can have a positive effect of liquid transport through the porous media (23). Based on these previous studies, we expect that adding a surfactant will achieve a lower surface tension between the cathode backbone and infiltrate solution, thus enabling the infiltrate to more easily penetrate into the cathode.

Surfactants are versatile materials used in diverse industries (i.e. chemical, pharmaceutical, cleaning, food, etc.). Surfactants lower the surface tension between two materials, such as the interface between two liquids or a liquid and a solid. One way to measure the effect of a surfactant on a liquid's surface tension is by using a goniometer. A goniometer is an instrument that can measure a liquid's surface tension, as well as the contact angle of a liquid in contact with a solid. The contact angle is typically calculated by first capturing a digital image of the droplet's side view, such that the liquid-solid surface is in the same plane as the camera's viewing angle. Then, image analysis software can be used to precisely measure the angle formed at the outer edge of the liquid droplet between the liquid-air boundary and solid-air boundary. In this study, a goniometer will be used to measure the effect of various types of surfactants and surfactant concentrations on infiltrate surface tension and contact angle with the cathode backbone material. 
A suitable surfactant concentration must be chosen in order to sufficiently reduce the infiltrate's surface tension, while also keeping the amount of surfactant added to the infiltrate to a minimum. One method of characterizing the amount of surfactant added to a liquid is by quantifying the critical micelle concentration (CMC). CMC is the surfactant concentration above which all additional surfactant goes into making micelles instead of individual surfactant molecules in solution. The CMC is important because typically a solution's surface tension lowers sharply when approaching CMC, but changes much less above the CMC. We will use the CMC literature values for the chosen surfactants to quantify the amount of surfactant added to the infiltrate solution.

Chelating agents are compounds that can form multiple bonds to a single metal ion. Citric acid is a chelating agent that has been shown to homogenously disperse metal ions through a process called sol-gel citrate method, which makes it easier to form the peroskite oxide structures. The sol-gel method results in good stoichiometric control and particle size distributions (24). Ghiasi et al. showed that elevated citric acid concentrations above a 1:1 molar ratio (moles of citric acid: moles of metal cations) had a negative effect on the formation of $\mathrm{LaMnO}_{3}$ perovskite crystalline phase (25). Nguyen et al. also found that using citric acid in a 1:1 molar ratio (moles of citric acid: moles of metal cations) assisted with making highly dispersed $\mathrm{LaCoO}_{3}$ perovskite (26). Taguchi et al. found that lower citric acid molar concentrations (0.5:1 moles of citric acid: moles of metal cations) resulted in good surface crystallinity and showed the highest catalytic activity for CO oxidation (27). Previous research supports the viewpoint that the chelating agent concentration should be no more than a 1:1 molar ratio in order to promote good crystallinity and phase formation.

Our goal was to develop a one-step infiltration method to deposit 8-10 weight percent of an 
electrocatalyst into the $\mathrm{La}_{0.6} \mathrm{Sr}_{0.4} \mathrm{Co}_{0.2} \mathrm{Fe}_{0.8} \mathrm{O}_{3-\delta}$ (LSCF) $-\mathrm{Ce}_{0.8} \mathrm{Sm}_{0.2} \mathrm{O}_{2}$ (SDC) cathode of a planar SOFC using an automated solution dispensing technique. The electrocatalyst used in this work was $\mathrm{La}_{0.6} \mathrm{Sr}_{0.4} \mathrm{CoO}_{3-\delta}$ (LSCo). We determined the effect of various compositional changes on the fuel cell performance and durability. The results of this experiment will guide the commercial deployment of infiltrated SOFCs by industry.

\section{Experimental}

LSCo electrocatalyst solutions were prepared at different molar ratios ranging from $0.5 \mathrm{M}$ to 1.0M using aqueous solutions of $\mathrm{La}\left(\mathrm{NO}_{3}\right)_{3} * 6 \mathrm{H}_{2} \mathrm{O}$ (Alfa Aesar, 99.9\%), $\mathrm{Sr}\left(\mathrm{NO}_{3}\right)_{2}$ (Alfa Aesar, 99.0\%), $\mathrm{Co}\left(\mathrm{NO}_{3}\right)_{2} * 6 \mathrm{H}_{2} \mathrm{O}$ (GFS Chemicals), and citric acid (Alfa Aesar, 99.5\%). LSCo was observed to precipitate at $1.2 \mathrm{M}$ when held at room temperature. Citric acid was added as a chelating agent to complex with the metal ions and to assist with forming the correct LSCo phase upon calcination. The citric acid concentration was based on the concentration of metal ions in solution. When the moles of citric acid equaled the moles of metal ions, the mixture was designated 1:1 for identification purposes. Other citric acid concentrations were tested, including 1:0.33 (moles of metal ions: moles of citric acid) and 1:0.67. LSCo solutions were also prepared using the following surfactants: Triton $^{\mathrm{TM}} \mathrm{X}-100$ (Sigma-Aldrich), sodium dodecylbenzenesulfonate (SDBS)(Sigma-Aldrich), and sodium dodecyl sulfate (SDS)(SigmaAldrich). The LSCo surfactant solutions were sonicated for $1 \mathrm{hr}$ to ensure adequate mixing and uniformity. The surfactants were added according to their CMCs. The CMCs for each surfactant are as follows: $0.23 \mathrm{mM}$ for Triton ${ }^{\mathrm{TM}} \mathrm{X}-100,1.6 \mathrm{mM}$ for SDBS, and $8.0 \mathrm{mM}$ for SDS. A summary of the testing parameters is provided in Table 1.

The electrocatalyst infiltrate solutions were applied to commercially available planar SOFCs 
made by MSRI (Materials and Systems Research Inc., Salt Lake City, UT). The anodesupported cells have an active area of $2.0 \mathrm{~cm}^{2}$. They are comprised of a $750 \mu \mathrm{m}$ thick Ni-YSZ anode, $10 \mu \mathrm{m}$ thick YSZ electrolyte, and 50-60 $\mu \mathrm{m}$ thick LSCF cathode. The anode also includes an anode functional layer and the cathode includes a $10 \mu \mathrm{m}$ thick SDC-LSCF functional layer.

A Sono-Tek ${ }^{\circledR}$ ultrasonic spray nozzle was used to atomize the infiltrate solution while spraying the infiltrate onto the cathode's surface. The infiltrated cells were then placed in a non-convection oven at $850^{\circ} \mathrm{C}$ for $2 \mathrm{~h}$ to calcine the electrocatalyst inside the porous cathode structure. At low molarities, multiple spray/calcination steps were required to ensure adequate loading. Therefore, the volume of infiltrate applied to each cell was dependent on the infiltrate molarity used. Thus, higher infiltrate concentrations were used in these studies to ensure adequate delivery in a single step. The infiltrate solution was applied to the surface of the cathode in order to achieve a loading of 8-10 weight percent based on the as-received cathode weight. The infiltrate weight percent target of 8-10 weight percent was selected due to previous performance improvements made by Lee et al (28).

The approach for testing the infiltrated cells consisted of four activities. First, a goniometer was used to measure the surface tension and contact angle of the different infiltrate solutions. Then, a scanning electron microscope (SEM) was used to probe the cathode structure to determine the location, size, and shape of the infiltrated nanocatalysts. Next, X-ray crystallography was used to obtain phase information for the post-fired infiltrate. Lastly, the infiltrated SOFC's were tested using a multi-cell array (MCA) to study performance and durability. 


\section{Goniometer}

The surface tension of each solution was measured with a goniometer (Ramé-hart Instrument Co.) using the pendant drop method. Additionally, the contact angles of the infiltrates on LSCF and SDC (Samarium $\left(\mathrm{Sm}_{2} \mathrm{O}_{3}\right)$ Doped Ceria $\left(\mathrm{CeO}_{2}\right)$ ) were measured using the sessile drop method. Since the MSRI cathode is comprised of a LSCF conducting layer and LSCF/SDC functional layer, LSCF and SDC pellets were used to study the contact angles. LSCF and SDC pellets were prepared by pressing LSCF and SDC powder, firing the pellets at $1350^{\circ} \mathrm{C}$ and $1450^{\circ} \mathrm{C}$, respectively, for 4 hours, then polishing the face of the pellet with 0.025 um silica. Multiple surface tension and contact angle measurements were made on each infiltrate to ensure reproducibility and statistically relevant data.

\section{Scanning Electron Microscopy}

Scanning electron microscopy (SEM, JEOL 7600F) was used to explore the cathode active layer microstructure prior to and after cathode infiltration. The SEM enabled us to ensure the infiltrate deposited in the cathode catalyst layer close to the electrolyte and the structure was consistent with past infiltration performance improvements.

\section{X-ray Diffraction}

X-ray diffraction (XRD, PanAnalytical X'pert Pro) was used to measure phase formation of the infiltrate after calcination. Phase information was important to ensure added surfactants and change in chelating agent concentration did not adversely change the material phase of the infiltrated catalyst.

\section{Multi-Cell Array}


All fuel cells were tested using the multi-cell array (MCA) located at the NETL Morgantown, WV site. The MCA simultaneously tested twelve cells in parallel using the same fuel and air composition, flow rate, and cell temperature. During MCA startup, the cells were initially heated to $750^{\circ} \mathrm{C}$ while flowing air to the cathode and pure nitrogen to the anode. After system temperature stabilized, the anode inlet stream was adjusted to $10 \%$ hydrogen - $90 \%$ nitrogen mixture. Over the next 7 hours, the anode inlet composition was increased stepwise to pure hydrogen. After flowing pure hydrogen to the anode for 24 hours, the cells were loaded to $0.25 \mathrm{~A} / \mathrm{cm}^{2}$ using a DC electronic load (Amrel ZVL 60-10-20). Electrochemical Impedance Spectroscopy (EIS) was used to determine cathode polarization resistances at periodic times during the MCA testing. Other details related to the MCA testing apparatus and procedure is explained in previous reports $(10,12,28)$.

\section{Results and Discussion}

Figure 1 compares the goniometer surface tension measurements for 3 different chelating agent concentrations (citric acid) and 3 different surfactants. 1M LSCo was used for all goniometer experiments. The surface tension and contact angle of water was used to ensure proper calibration of the goniometer. As expected, lower surface tension resulted when adding the surfactants to the infiltrate solution. When varying the citric acid concentration in LSCo without using a surfactant, the $33 \%$ citric acid case resulted in lower surface tension as compared to both the $67 \%$ and $100 \%$ citric acid cases. Figure 2 compares the goniometer contact angle measurements for different solutions in contact with either a LSCF or SDC pellet. For Figure 2, the surfactant concentrations were made using the $100 \% \mathrm{CMC}$. We

found that Triton ${ }^{\mathrm{TM}} \mathrm{X}-100$ had the largest effect on lowering the contact angle of the LSCo solution. SDBS also lowered the contact angle of the LSCo solution, but not as much as 
Triton ${ }^{\mathrm{TM}} \mathrm{X}-100$. SDS did not cause an appreciable decline in contact angle. Additionally, we noticed that a 1:0.33 chelating agent concentration results in lower surface tension than when using 1:0.67 or 1:1 chelating agent concentration. We observed a low solubility of SDS and SDBS in the 1M LSCo solution due to the precipitation of the surfactant when allowed to sit for extended periods of time (days). Sonication was used when adding the surfactant to the LSCo solution to ensure uniform mixing. We did not observe any precipitation of Triton ${ }^{\mathrm{TM}}$ $\mathrm{X}-100$ in LSCo since Triton ${ }^{\mathrm{TM}} \mathrm{X}-100$ is an aqueous solution.

In order to offer an explanation for the difference in contact angle and surface tension measurements between each surfactant, the following surfactant characteristics must be considered. First, Triton ${ }^{\mathrm{TM}} \mathrm{X}-100$ is a nonionic surfactant, whereas SDBS and SDS are both anionic surfactants. Additionally, the chemical structures of Triton ${ }^{\mathrm{TM}} \mathrm{X}-100$ and SDS are considerably larger than the chemical structure of SDBS. Moreover, pure $\operatorname{Triton}^{\mathrm{TM}} \mathrm{X}-100$ is an aqueous solution, whereas pure SDS and SDBS are solid powders at room temperature. Lastly, the CMC for each surfactant is different. These dissimilarities are expected to contribute to variations in contact angle and surface tension measurements.

Next, we used the SEM to probe the cathode microstructure after infiltration to ensure adequate and uniform nanocatalyst deposition. Based on previous experiments, we expected to observe a correlation of round uniform deposition of nanocatalyst throughout the cathode active layer with a good performing cathode. SEM images were captured with and without using a surfactant, as well as with varying compositions of citric acid concentrations. Images were captured prior to and after 200 hours of fuel cell operation. Generally, we observed a coating layer of infiltrate on the SDC backbone, as well as a distribution of spherical-like nanoparticles on the LSCF backbone. SEM energy-dispersive X-ray spectroscopy (EDS) 
verified that the coating layer and spherical-like nanoparticles were in fact LSCo infiltrate. When lowering the citric acid concentration to 1:0.33 with 1M LSCo, we observed better infiltrate deposition onto the cathode active catalyst layer. We suspect this is mainly due to the lower viscosity resulting in better transport of the solution through the cathode microstructure during the infiltration process. Figure 3A shows the SEM image after 200 hours of fuel cell operation using 1M LSCo, 1:0.33 citric acid concentration and no surfactant. This cell had good performance relative to the baseline infiltrate cell using 1:1 citric acid and no surfactant. We observed both the coating-like and round spherical particle deposition for this cell. Figure 3A shows extensive deposition in the lower portion of the SEM image. Figure 3B shows the SEM image after 200 hours of fuel cell operation using 1M LSCo, 1:1 citric acid concentration and no surfactant. From the SEM analysis of Figure 3, we observe better penetration of infiltrate into the cathode when using a lower concentration of citric acid $(33 \%)$.

In order to determine the effect of surfactant concentration on infiltration, we varied the amount of surfactant added to 1M LSCo. The effect of SDS and Triton ${ }^{\mathrm{TM}} \mathrm{X}-100 \mathrm{CMC}$ at beginning of life (BOL) is shown in Figure 4. By comparing Figure 4 images labeled A and B, we can see that by increasing the amount of surfactant from $50 \%$ to $100 \% \mathrm{CMC}$ we observe a greater amount of infiltrate deposited in the cathode active catalyst layer. A similar conclusion can be drawn by comparing Figure 4 images labeled $\mathrm{C}$ and $\mathrm{D}$, which is $50 \%$ and $100 \%$ CMC of Triton ${ }^{\mathrm{TM}} \mathrm{X}-100$, respectively. From the SEM analysis of Figure 4, we observe better penetration of infiltrate into the cathode when using a higher concentration of surfactant (100\% CMC).

XRD was used to analyze post-fired LSCo using different concentrations of citric acid. With 
XRD, we were able to confirm that a lower citric acid concentration does not negatively affect LSCo perovskite formation. Four different citric acid concentrations were used in the XRD analysis. From Figure 5, we observed similar results and corresponding LSCo peaks when using either $33 \%(1: 0.33)$ (moles of metal ions to moles of citric acid), $50 \%(1: 0.5)$, $67 \%$ (1:0.67), or 100\% citric acid (1:1). This information supports the idea that using a lower citric acid concentration will enable us more easily penetrate the porous cathode while continuing to make LSCo perovskite phase.

Spraying infiltration parameters and resultant weight increase of tested cells are summarized in Table 2. When the substrate temperature was heated above $30^{\circ} \mathrm{C}$ while applying infiltrate using the Sono-Tek ${ }^{\circledR}$ ultrasonic spray nozzle, we observed caking of infiltrate onto the top outer surface of the cathode. Thereafter, we applied infiltrates using a $20^{\circ} \mathrm{C}$ substrate temperature in order to prevent infiltrate drying on the cathode's top surface vice inside the cathode active catalyst layer. After heat-treating the infiltrated fuel cells to $850^{\circ} \mathrm{C}$ for 2 hours, their weights were measured in order to calculate the total amount of infiltrate deposited into the cathode. By comparing the infiltrate weight of cells 1, 2, and 3 in Table 2, we observe that less infiltrate was deposited into the cathode at temperatures above $30^{\circ} \mathrm{C}$. Also by comparing cells 10, 11, and 12 in Table 2, we observe that more infiltrate is deposited into the cathode when we use a citric acid concentration of 1:0.33 vice 1:0.50 or 1:0.67. Therefore, for cells 13 thru 24, a citric acid concentration of 1:0.33 was used to enable more infiltrate to penetrate into the cathode. By comparing cells 16-18, 19-21, and 22-24, we observe that SDS and Triton $^{\mathrm{TM}} \mathrm{X}-100$ enable better penetration of the infiltrate into the cathode than SDBS, thus resulting in increased infiltrate weights for SDS and Triton ${ }^{\mathrm{TM}} \mathrm{X}-100$.

Figure 6 shows the impedance analysis for a baseline cell (grey line with triangle markers) 
without any infiltrate deposited in the cathode. For Figure 6, the baseline cell impedance spectra were obtained at the following operating times: $0 \mathrm{~h}, 24 \mathrm{~h}, 100 \mathrm{~h}, 200 \mathrm{~h}$, and $300 \mathrm{~h}$. A grey arrow is used in Figure 6 to indicate the impedance trend with increasing operating time. Based on previous work, we have observed a drop in impedance in the range of about 10 to $300 \mathrm{~Hz}$ when infiltrating the cathode with LSCo. Past research has correlated the impedance in the 10 to $300 \mathrm{~Hz}$ range with cathode surface exchange reaction and activation $(10,28)$. In addition to activation effect by infiltration, a high impedance in the 0.1 to $1 \mathrm{~Hz}$ range usually indicated that the cathode is physically blocked and is causing a gas diffusion limitation (10). Figure 6A compares the impedance analysis of a baseline cell with that of a 1M LSCo with $100 \%$ CMC SDS and 1:1 citric acid concentration. For the 10-300 Hz range, the SDS infiltrated cell maintained better performance throughout the run. Figure 6B and Figure 6C compare the $100 \%$ CMC Triton ${ }^{\mathrm{TM}} \mathrm{X}-100$ and $100 \%$ CMC SDBS infiltrated cells to the baseline cell, respectively. Compared to the baseline cell, the SDS infiltrated cell shows some gas diffusion limitation in the 0.1 to $1 \mathrm{~Hz}$ range, while the SDBS infiltrated cells show very little gas diffusion limitation and Triton ${ }^{\mathrm{TM}} \mathrm{X}-100$ infiltrated cell has negligible gas diffusion limitation. Figure 7 and Figure 8 graph the polarization and power curves at BOL and after $200 \mathrm{hrs}$ of operation, respectively. All three single-step infiltration methods with surfactants performed better after 200 hours of operation than the multi-step baseline cell when using 1:1 citric acid concentration.

Figure 9A shows the impedance analysis for a 1M LSCo, 1:0.33 citric acid and no surfactant. Figure 9B, Figure 9C, and Figure 9D illustrate the impedance analysis for SDS, $\operatorname{Triton}^{\mathrm{TM}} \mathrm{X}$ 100, and SDBS, respectively. All infiltrates containing 1:0.33 citric acid concentration performed comparatively well with little degradation over time in the $10-300 \mathrm{~Hz}$ range. Figure 9B shows degradation in the $1000 \mathrm{~Hz}$ range, correlating to degradation of the anode 
(10). The anode degradation may mask the performance improvement using SDS up to 200 hrs of operation. We don't anticipate that the anode degradation in the $1000 \mathrm{~Hz}$ range of Figure 9B has any correlation to cathode infiltrating. Figure 10 and Figure 11 graph the polarization and power curves at BOL and after $200 \mathrm{hrs}$ of operation, respectively. All three single-step infiltration methods with surfactants performed better after 200 hours of operation than the multi-step baseline cell when using 1:0.33 citric acid concentrations. Additionally, the 1:0.33 citric acid concentrations performed better than the 1:1 citric acid concentration. Finally, when comparing the V-I curves for the 1:1 citric acid concentrations (Figure 8) versus the 1:0.3 citric acid concentrations (Figure 11), we only observe the "voltage tail drop" phenomenon at high current density for the 1:1 citric acid concentration samples. The steep voltage drop at high current density is one evidence that there must be gas diffusion limitation in the cell.

\section{Conclusions}

In this work, we developed a one-step infiltration method to deposit 8-10 weight percent of LSCo electrocatalyst into the LSCF cathode of a planar SOFC using an automated ultrasonic solution dispensing technique. We determined the effect of substrate temperature, surfactant use, and citric acid concentration on fuel cell performance and durability. We observed better infiltration of the cathode when using lower substrate temperature, $20^{\circ} \mathrm{C}$ vice $40^{\circ} \mathrm{C}$. Additionally, we found that using a surfactant enabled better infiltrate penetration into the cathode, resulting in better fuel cell performance and durability. Surface tension, contact angle, and solubility measurement indicated that $\operatorname{Triton}^{\mathrm{TM}} \mathrm{X}-100$ was the best fit among the surfactants investigated in this study for highly concentrated infiltration solution and a LSCFSDC composite backbone. Finally, we found that reducing the citric acid concentration to a 
ratio of 1:0.33 enabled better infiltrate penetration into the cathode and increased fuel cell performance while also reducing cathode degradation, as shown in the 10-100 $\mathrm{Hz}$ impedance range. The final recommendation for cathode infiltration of a planar SOFC using LSCo and an ultrasonic spray coater are to maintain the substrate temperature at $20 \mathrm{C}$, use a citric acid concentration ratio of 1:0.33, and use the $100 \%$ CMC of a surfactant such as SDS or Triton ${ }^{\mathrm{TM}}$ $\mathrm{X}-100$.

\section{Acknowledgements}

The authors acknowledge the financial support of this work by the U.S. DOE NETL (National Energy Technology Laboratory). This technical effort was performed in support of the NETL's ongoing research under the RES contract DE-FE0004000. 


\section{References}

1. J. D. Larminie and A. Dicks, Fuel cell systems explained, Chapter Title: Medium and High Temperature Fuel Cells, Chapter Number: 7, 168-177 (2003), John Wiley \& Sons Ltd, Chichester, England, ISBN 0-470-84857-X.

2. Y. Bicer and I. Dincer, International Journal of Hydrogen Energy, "Energy and exergy analyses of an integrated underground coal gasification with SOFC fuel cell system for multigeneration including hydrogen production”, 40, 13323-13337 (2015), DOI: 10.1016/j.ijhydene.2015.08.023.

3. N. S. Siefert and S. Litster, Journal of Power Sources, "Exergy \& economic analysis of biogas fueled solid oxide fuel cell systems”, 272, 386-397 (2014), DOI: 10.1016/j.jpowsour.2014.08.044.

4. S. P. Jiang, Materials Science and Engineering A, "A review of wet impregnation An alternative method for the fabrication of high performance and nano-structured electrodes of solid oxide fuel cells", 418, 199-210 (2006), DOI: 10.1016/j.msea.2005.11.052.

5. S. P. Jiang, International Journal of Hydrogen Energy, "Nanoscale and nanostructured electrodes of solid oxide fuel cells by infiltration: Advances and challenges", 37, 449-470 (2012), DOI: 10.1016/j.ijhydene.2011.09.067.

6. L. Adijanto, R. Küngas, J. Park, J. M. Vohs and R. J. Gorte, International Journal of Hydrogen Energy, "SOFC anodes based on infiltration of tungsten bronzes", 36, 1572215730 (2011), DOI: 10.1016/j.ijhydene.2011.09.059.

7. R. Fernández-González, J. C. Ruiz-Morales, J. Canales-Vázquez, J. R. Jurado, A. Makradi and P. Núñez, International Journal of Hydrogen Energy, "Decreasing the polarization resistance of a Ni-YSZ solid oxide fuel cell anode by infiltration of a ceria-based solution”, In Press, 1-6 (2016), DOI: 10.1016/j.ijhydene.2016.03.092. 
8. G. Li, B. He, Y. Ling, J. Xu and L. Zhao, International Journal of Hydrogen Energy,

"Highly active YSB infiltrated LSCF cathode for proton conducting solid oxide fuel cells", 40, 13576-13582 (2015), DOI: 10.1016/j.ijhydene.2015.07.164.

9. X. Zhang, L. Liu, Z. Zhao, L. Shang, B. Tu, D. Ou, D. Cui and M. Cheng, International Journal of Hydrogen Energy, "High performance solid oxide fuel cells with $\mathrm{Co}_{1.5} \mathrm{Mn}_{1.5} \mathrm{O}_{4}$ infiltrated (La,Sr) $\mathrm{MnO}_{3}$-yittria stabilized zirconia cathodes”, 40, 3332-3337 (2015), DOI: 10.1016/j.ijhydene.2015.01.040.

10. S. Lee, N. Miller and K. Gerdes, Journal of the Electrochemical Society, "Long-Term Stability of SOFC Composite Cathode Activated by Electrocatalyst Infiltrations", 159 (7), F301-F308 (2012), DOI: 10.1149/2.067207jes.

11. S. Lee, N. Miller, H. Abernathy, K. Gerdes and A. Manivannan, Journal of The Electrochemical Society, "Effect of Sr-Doped $\mathrm{LaCoO}_{3}$ and $\mathrm{LaZrO}_{3}$ Infiltration on the Performance of SDC-LSCF Cathode", 158 (6), B735-B742 (2011), DOI: 10.1149/1.3581026. 12. S. Lee, N. Miller, M. Staruch, K. Gerdes, M. Jain and A. Manivannan, Electrochimica Acta, $" \operatorname{Pr}_{0.6} \mathrm{Sr}_{0.4} \mathrm{CoO}_{3-\delta}$ electrocatalyst for solid oxide fuel cell cathode introduced via infiltration", 56, 9904-9909 (2011), DOI: 10.1016/j.electacta.2011.08.060.

13. X. Li, N. Xu, X. Zhao and K. Huang, Journal of Power Sources, "Performance of a commercial cathode-supported solid oxide fuel cells prepared by single-step infiltration of an ion-conducting electrocatalyst", 199, 132-137 (2012), DOI:10.1016/j.jpowsour.2011.10.079.

14. K. Chen, N. Ai and S. P. Jiang, International Journal of Hydrogen Energy, "Enhanced electrochemical performance and stability of ( $\mathrm{La}, \mathrm{Sr}) \mathrm{MnO}_{3}-(\mathrm{Gd}, \mathrm{Ce}) \mathrm{O}_{2}$ oxygen electrodes of solid oxide electrolysis cells by palladium infiltration”, 37, 1301-1310 (2012), DOI: 10.1016/j.ijhydene.2011.10.015.

15. H. Fan, M. Keane, N. Li, D. Tang, P. Singh and M. Han, International Journal of Hydrogen Energy, "Electrochemical stability of $\mathrm{La}_{0.6} \mathrm{Sr}_{0.4} \mathrm{Co}_{0.2} \mathrm{Fe}_{0.8} \mathrm{O}_{3-\delta}$ infiltrated YSZ 
oxygen electrode for reversible solid oxide fuel cells", 39, 14071-14078 (2014), DOI: 10.1016/j.ijhydene.2014.05.149.

16. A. R. Hanifi, M. A. Laguna-Bercero, T. H. Etsell and P. Sarkar, International Journal of Hydrogen Energy, "The effect of electrode infiltration on the performance of tubular solid oxide fuel cells under electrolysis and fuel cell modes”, 39, 8002-8008 (2014), DOI: 10.1016/j.ijhydene.2014.03.071.

17. K. S. Howe, A. R. Hanifi, K. Kendall, M. Zazulak, T. H. Etsell and P. Sarkar, International Journal of Hydrogen Energy, "Performance of microtubular SOFCs with infiltrated electrodes under thermal cycling”, 38, 1058-1067 (2013), DOI: 10.1016/j.ijhydene.2012.10.098.

18. M. A. Laguna-Bercero, A. R. Hanifi, T. H. Etsell, P. Sarkar and V. M. Orera, International Journal of Hydrogen Energy, "Microtubular solid oxid fuel cells with lanthanum strontium manganite infiltrated cathodes”, 40, 5469-5474 (2015), DOI: 10.1016/j.ijhydene.2015.01.060.

19. Z. Zhou, D. Han, H. Wu and S. Wang, International Journal of Hydrogen Energy, "Fabrication of planar-type SOFC single cells by a novel vacuum dip-coating and co-firing infiltration techniques", 39, 2274-2278 (2014), DOI: 10.1016/j.ijhydene.2013.11.061.

20. Z. Jiang, C. Xia, F. Zhao and F. Chen, Electrochemical and Solid-State Letters, " $\mathrm{La}_{0.85} \mathrm{Sr}_{0.15} \mathrm{MnO}_{3}$ - Infiltrated $\mathrm{Y}_{0.5} \mathrm{Bi}_{1.5} \mathrm{O}_{3}$ Cathodes for Intermediate-Temperature Solid Oxide Fuel Cells", 12, B91-B93 (2009), DOI: 10.1149/1.3099321.

21. I. G. Godinez and C. J. Darnault, Water Research, "Aggregation and transport of nano- $\mathrm{TiO}_{2}$ in saturated porous media: Effects of ph, surfactants and flow veloicty", 45, 839851 (2011), DOI:10.1016/j.watres.2010.09.013.

22. X. Zhu, D. Ding, Y. Li, Z. Lü, W. Su and L. Zhen, International Journal of Hydrogen Energy, "Development of $\mathrm{La}_{0.6} \mathrm{Sr}_{0.4} \mathrm{Co}_{0.2} \mathrm{Fe}_{0.8} \mathrm{O}_{3-\delta}$ - cathode with an improved stability via 
$\mathrm{La}_{0.8} \mathrm{Sr}_{0.2} \mathrm{MnO}_{3}$-film impregnation”, 38, 5375-5382 (2013), DOI:

10.1016/j.ijhydene.2013.02.091.

23. V. M. Starov, S. A. Zhdanov and M. G. Velarde, Journal of Colloid and Interface Science, "Capillary imbibition of surfactant solutions in porous media and thin capillaries: partial wetting case", 273, 589-595 (2004), DOI:10.1016/j.jcis.2004.02.033.

24. L. Predoana, B. Malic and M. Zaharescu, Journal of Thermal Analysis and Calorimetry, "LaCoO 3 formation from precursors obtained by water-based sol-gel method with citric acid", 98, 361-366 (2009), DOI:10.1007/s10973-009-0315-x.

25. E. Ghiasi, A. Malekzadeh and M. Ghiasi, Journal of Rare Earths, "Moderate concentration of citric acid for the formation of $\mathrm{LaMnO}_{3}$ and $\mathrm{LaCoO}_{3}$ nano-perovskites", 31 (10), 997-1002 (2013), DOI: 10.1016/S1002-0721(12)60393-7.

26. S. V. Nguyen, V. Szabo, D. Trong On and S. Kaliaguine, Microporous and Mesoporous Materials, "Mesoporous silica supported LaCoO3 perovskites as catalysts for methane oxidation", 54, 51-61 (2002), DOI: 10.1016/S1387-1811(02)00340-2.

27. H. Taguchi, S. Yamada, M. Nagao, Y. Ichikawa and K. Tabata, Materials Research Bulletin, "Surface characterization of $\mathrm{LaCoO}_{3}$ synthesized using citric acid", 37, 69-76 (2002), DOI: 10.1016/S0025-5408(01)00799-1.

28. S. Lee, N. Miller, H. Abernathy, K. Gerdes, A. Manivannan, Journal of The Electrochemical Society, "Effect of Sr-Doped LaCoO3 and LaZrO3 Infiltration on the Performance of SDC-LSCF Cathode, 158 (6), B735-B742 (2011), DOI: 10.1149/1.3581026. 
Table 1: Experimental Variables

\begin{tabular}{|l|l|l|l|}
\hline Electrocatalyst & Baseplate Heating & Surfactant & Chelating Agent \\
\hline LSCo & $20^{\circ}, 30^{\circ}$, or $40^{\circ} \mathrm{C}$ & None, Triton X-100, SDBS, or SDS & Citric Acid \\
\hline
\end{tabular}


Table 1: MCA Testing Schedule

\begin{tabular}{|c|c|c|c|c|c|}
\hline $\begin{array}{c}\text { Cell } \\
\#\end{array}$ & Infiltrate & $\begin{array}{l}\text { Surfactant } \\
\text { (CMC) }\end{array}$ & $\begin{array}{c}\text { Citric Acid } \\
\text { Concentration } \\
\text { (moles of metal ions : } \\
\text { moles of citric acid) }\end{array}$ & $\begin{array}{c}\text { Substrate } \\
\text { Temperature } \\
\left({ }^{\circ} \mathrm{C}\right)\end{array}$ & $\begin{array}{c}\text { Infiltrate } \\
\text { Wt } \\
(\mathbf{m g})\end{array}$ \\
\hline 1 & $1 \mathrm{M} \mathrm{LSCo}$ & None & $1: 1$ & 20 & 3.1 \\
\hline 2 & $1 \mathrm{M} \mathrm{LSCo}$ & None & $1: 1$ & 30 & 3.2 \\
\hline 3 & $1 \mathrm{M} \mathrm{LSCo}$ & None & $1: 1$ & 40 & 2.8 \\
\hline 4 & $1 \mathrm{M} \mathrm{LSCo}$ & $100 \%$ CMC SDS & $1: 1$ & 20 & 3.2 \\
\hline 5 & $1 \mathrm{M}$ LSCo & $100 \%$ CMC SDS & $1: 1$ & 20 & 3.1 \\
\hline 6 & 1M LSCo & $100 \%$ CMC Triton X-100 & $1: 1$ & 20 & 3.0 \\
\hline 7 & $1 \mathrm{M} \mathrm{LSCo}$ & $100 \%$ CMC Triton X-100 & $1: 1$ & 20 & 3.1 \\
\hline 8 & $1 \mathrm{M} \mathrm{LSCo}$ & $100 \%$ CMC SDBS & $1: 1$ & 20 & 3.0 \\
\hline 9 & 1M LSCo & $100 \%$ CMC SDBS & $1: 1$ & 20 & 2.8 \\
\hline 10 & $1 \mathrm{M} \mathrm{LSCo}$ & None & $1: 0.33$ & 20 & 4.2 \\
\hline 11 & $1 \mathrm{M} \mathrm{LSCo}$ & None & $1: 0.50$ & 20 & 3.9 \\
\hline 12 & $1 \mathrm{M}$ LSCo & None & $1: 0.67$ & 20 & 3.6 \\
\hline 13 & $1 \mathrm{M}$ LSCo & None & $1: 0.33$ & 20 & 4.0 \\
\hline 14 & $1 \mathrm{M} \mathrm{LSCo}$ & None & $1: 0.33$ & 20 & 4.0 \\
\hline 15 & $1 \mathrm{M} \mathrm{LSCo}$ & None & $1: 0.33$ & 20 & 4.0 \\
\hline 16 & $1 \mathrm{M} \mathrm{LSCo}$ & $100 \%$ CMC SDS & $1: 0.33$ & 20 & 4.0 \\
\hline 17 & $1 \mathrm{M} \mathrm{LSCo}$ & $100 \%$ CMC SDS & $1: 0.33$ & 20 & 4.0 \\
\hline 18 & 1M LSCo & $100 \%$ CMC SDS & $1: 0.33$ & 20 & 3.8 \\
\hline 19 & $1 \mathrm{M} \mathrm{LSCo}$ & $100 \%$ CMC Triton X-100 & $1: 0.33$ & 20 & 4.0 \\
\hline 20 & $1 \mathrm{M} \mathrm{LSCo}$ & $100 \%$ CMC Triton X-100 & $1: 0.33$ & 20 & 4.1 \\
\hline 21 & $1 \mathrm{M} \mathrm{LSCo}$ & $100 \%$ CMC Triton X-100 & $1: 0.33$ & 20 & 4.0 \\
\hline 22 & $1 \mathrm{M} \mathrm{LSCo}$ & $100 \%$ CMC SDBS & $1: 0.33$ & 20 & 3.8 \\
\hline 23 & $1 \mathrm{M} \mathrm{LSCo}$ & $100 \%$ CMC SDBS & $1: 0.33$ & 20 & 3.9 \\
\hline 24 & 1M LSCo & $100 \%$ CMC SDBS & $1: 0.33$ & 20 & 3.8 \\
\hline
\end{tabular}


Figure 1

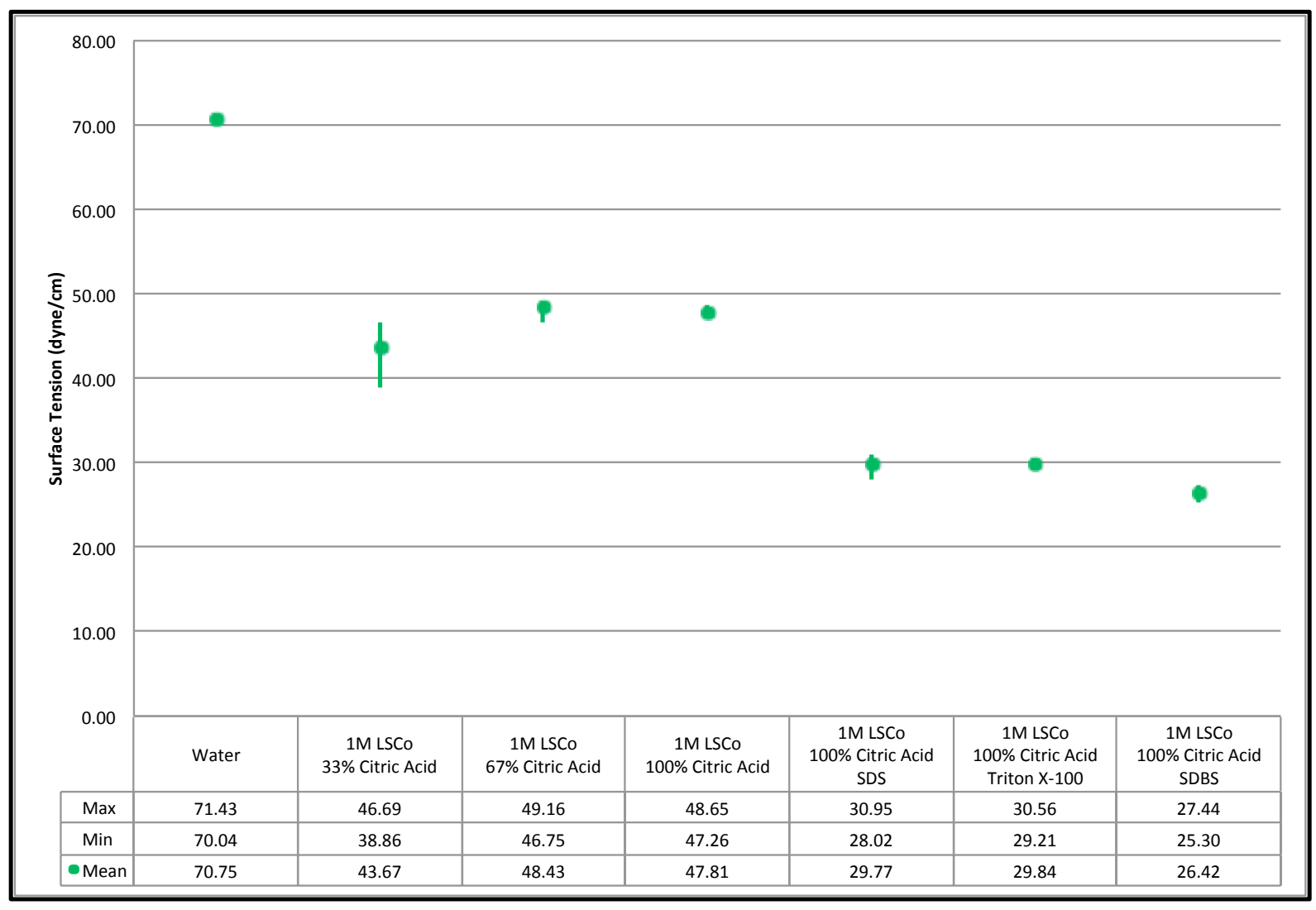

Figure 1. Surface Tension Measurements 
Figure 2

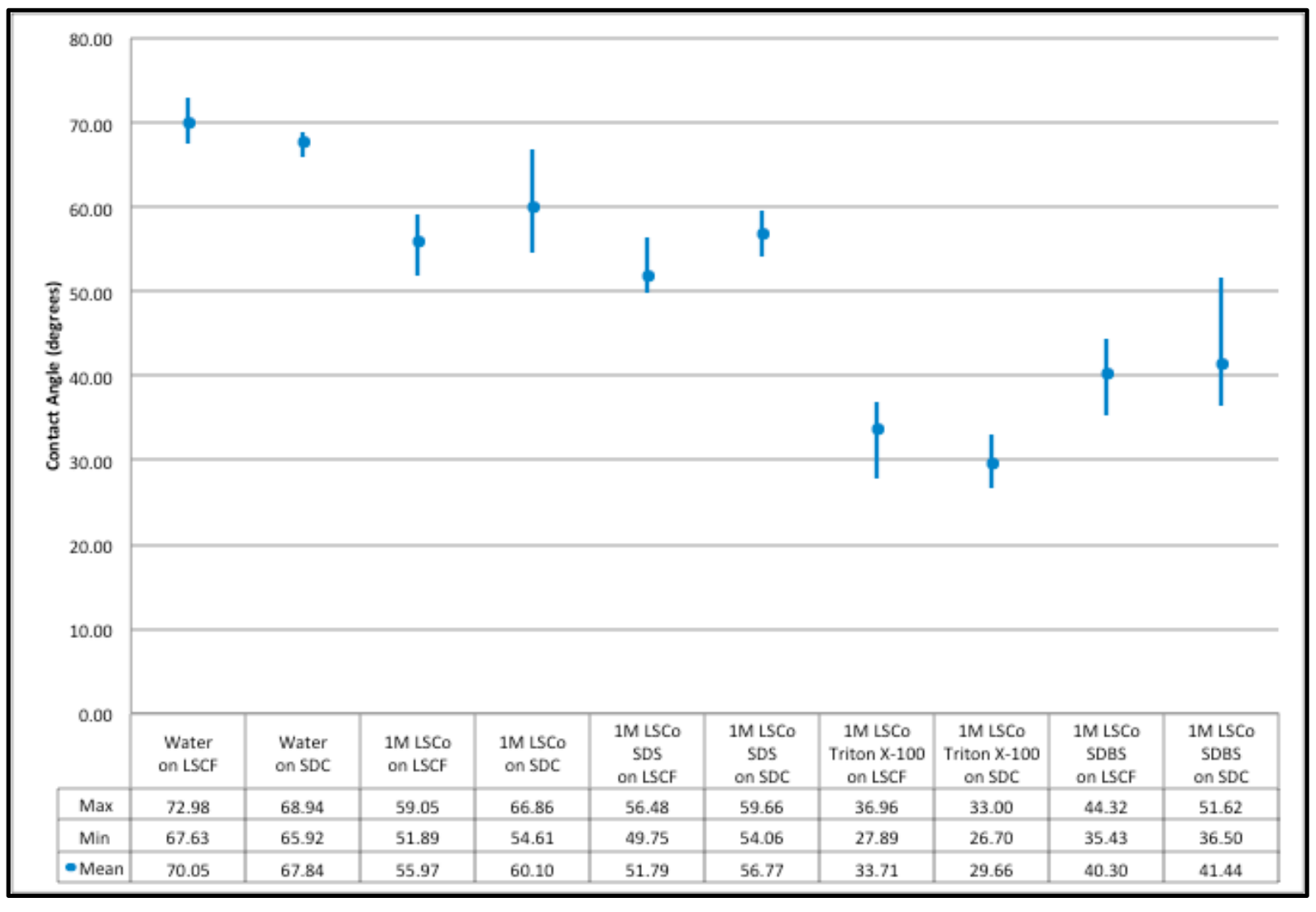

Figure 2: Contact Angle Measurements 
Figure 3

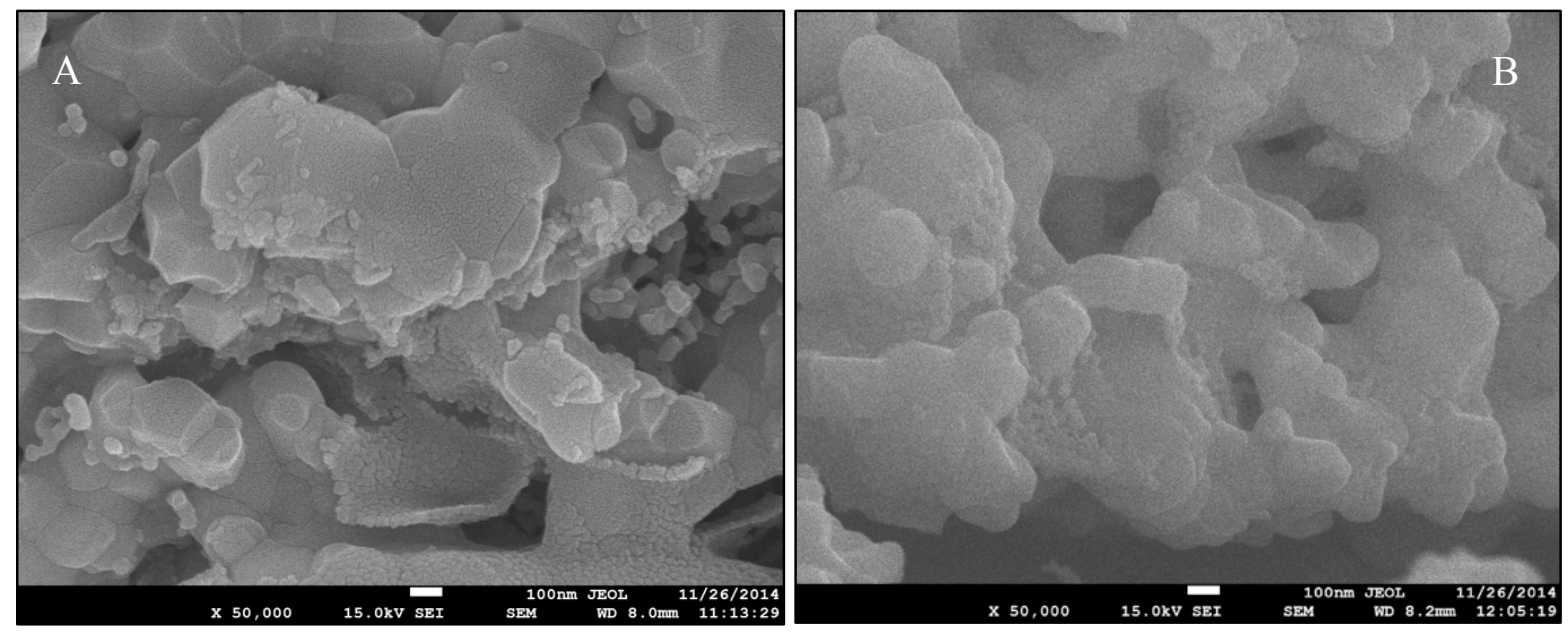

Figure 3: SEM images of Cathode Active Catalyst Layer using 1M LSCo and No Surfactant with (A) 1:0.33 Citric Acid, and (B) 1:1 Citric Acid after MCA Testing for $200 \mathrm{Hrs}$ 


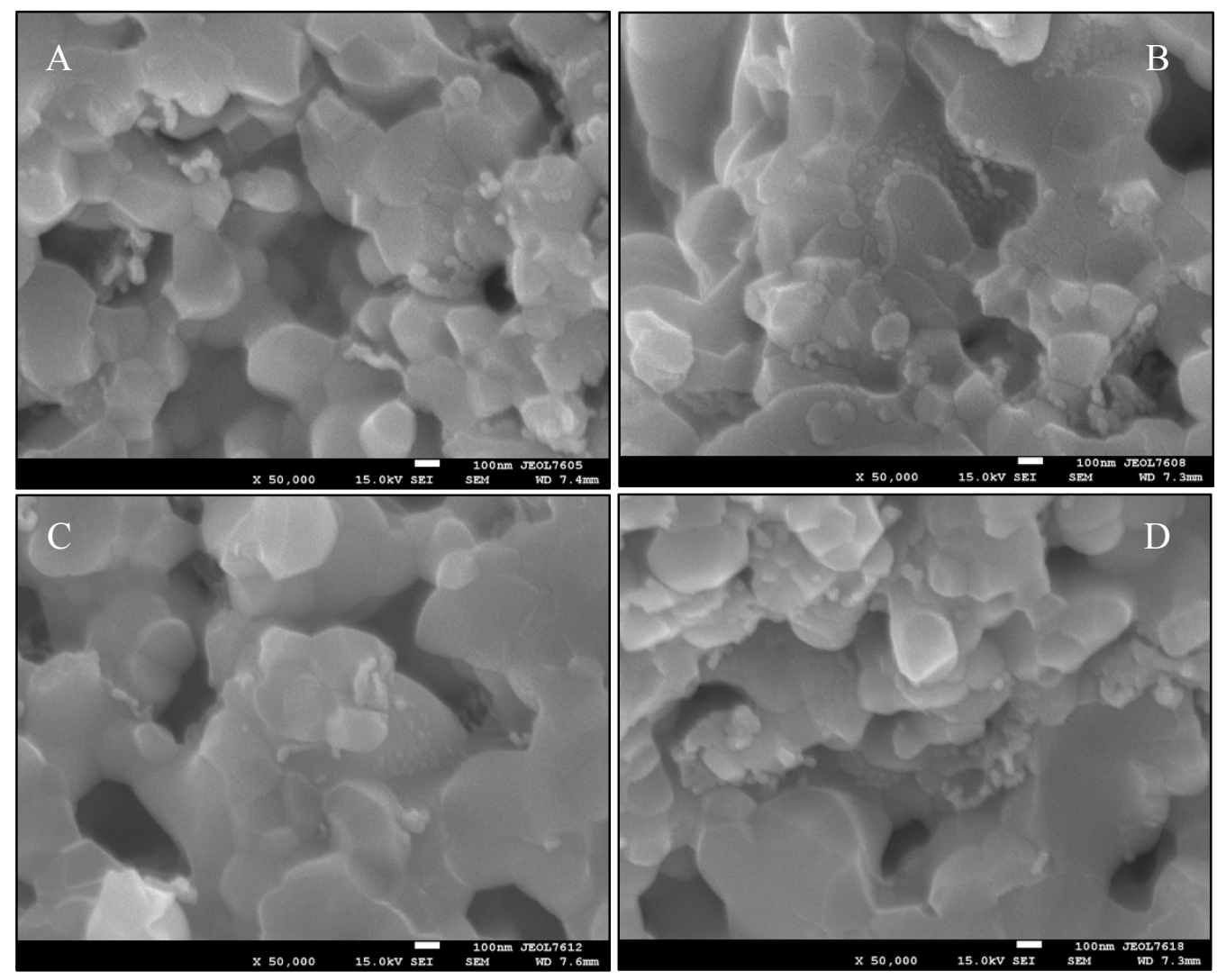

Figure 4: SEM Images of BOL Cathode Active Catalyst Layer using 1M LSCo with 1:1 Citric Acid and (A) 50\% CMC SDS, (B) 100\% CMC SDS, (C) 50\% CMC Triton X-100, and (D) $100 \%$ CMC Triton X-100 


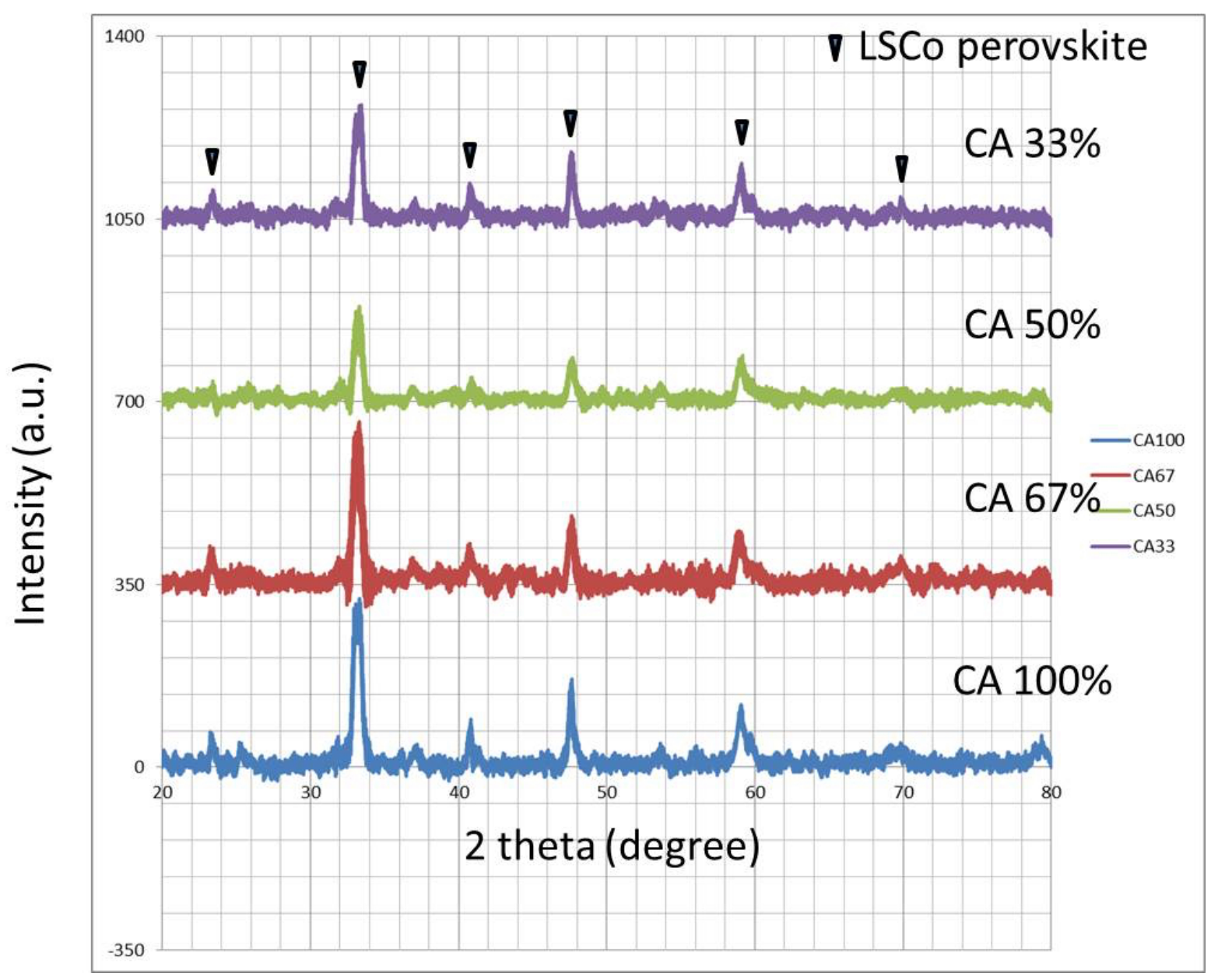

Figure 5: XRD Results for LSCo Perovskite Formation 


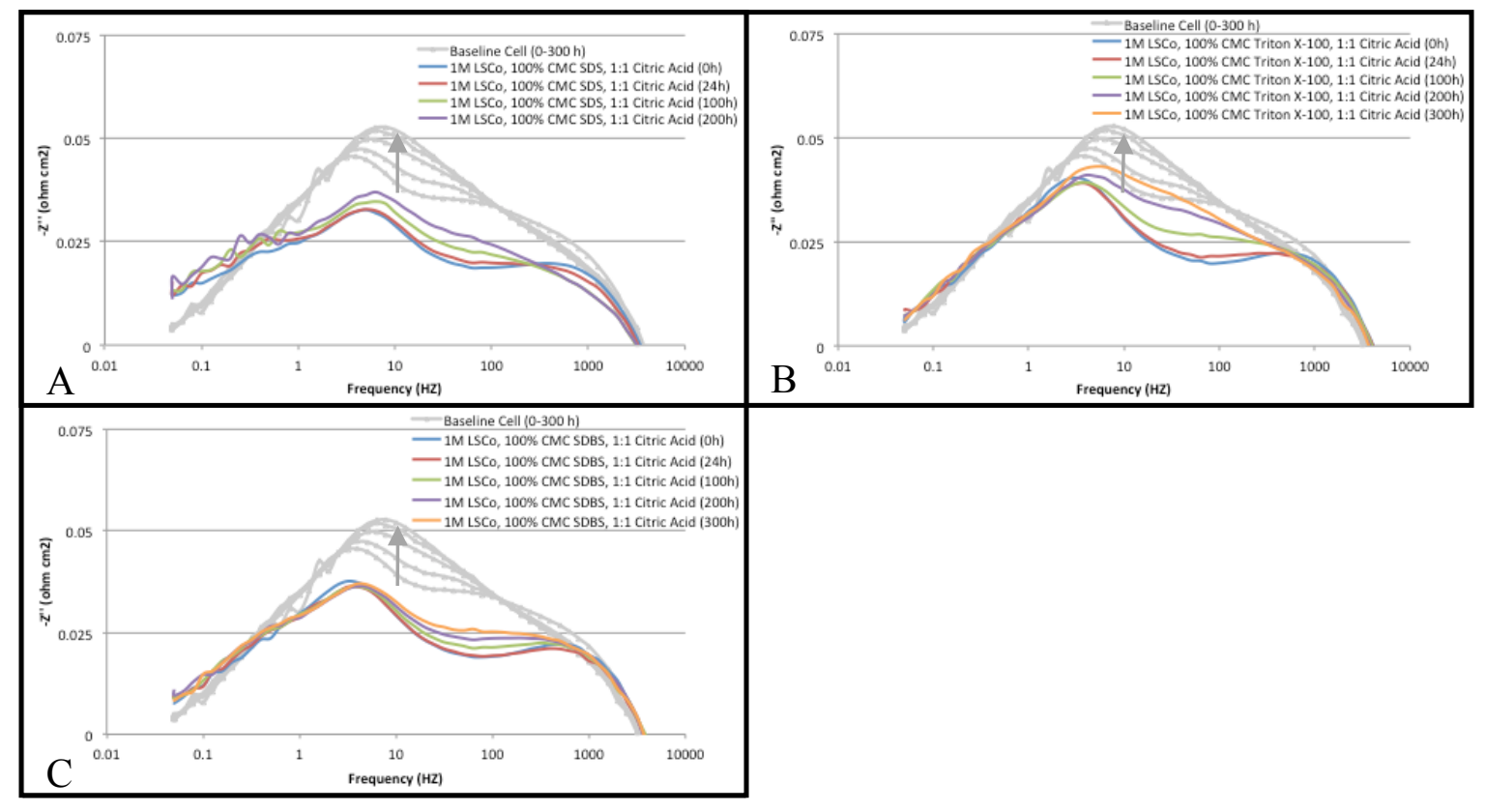

Figure 6: Impedance Analysis for 1M LSCo with 1:1 Citric Acid and (A) 100\% CMC SDS, (B) 100\% CMC Triton X-100, (C) 100\% CMC SDBS Infiltrated Cells versus Baseline Cell 


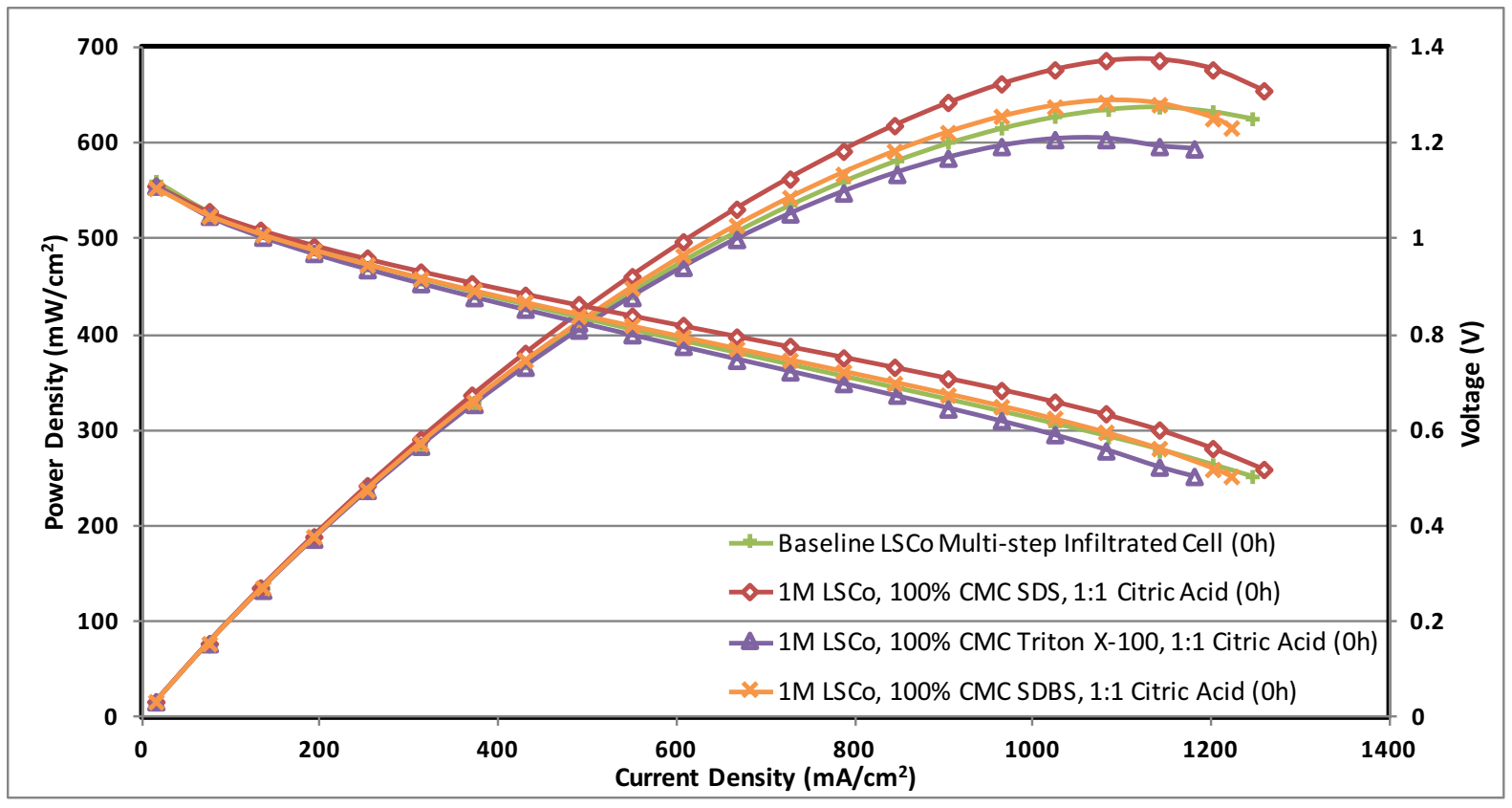

Figure 7: Polarization and Power Curves of Single-Step Infiltrated Cells versus Multi-Step Baseline Cell at BOL 


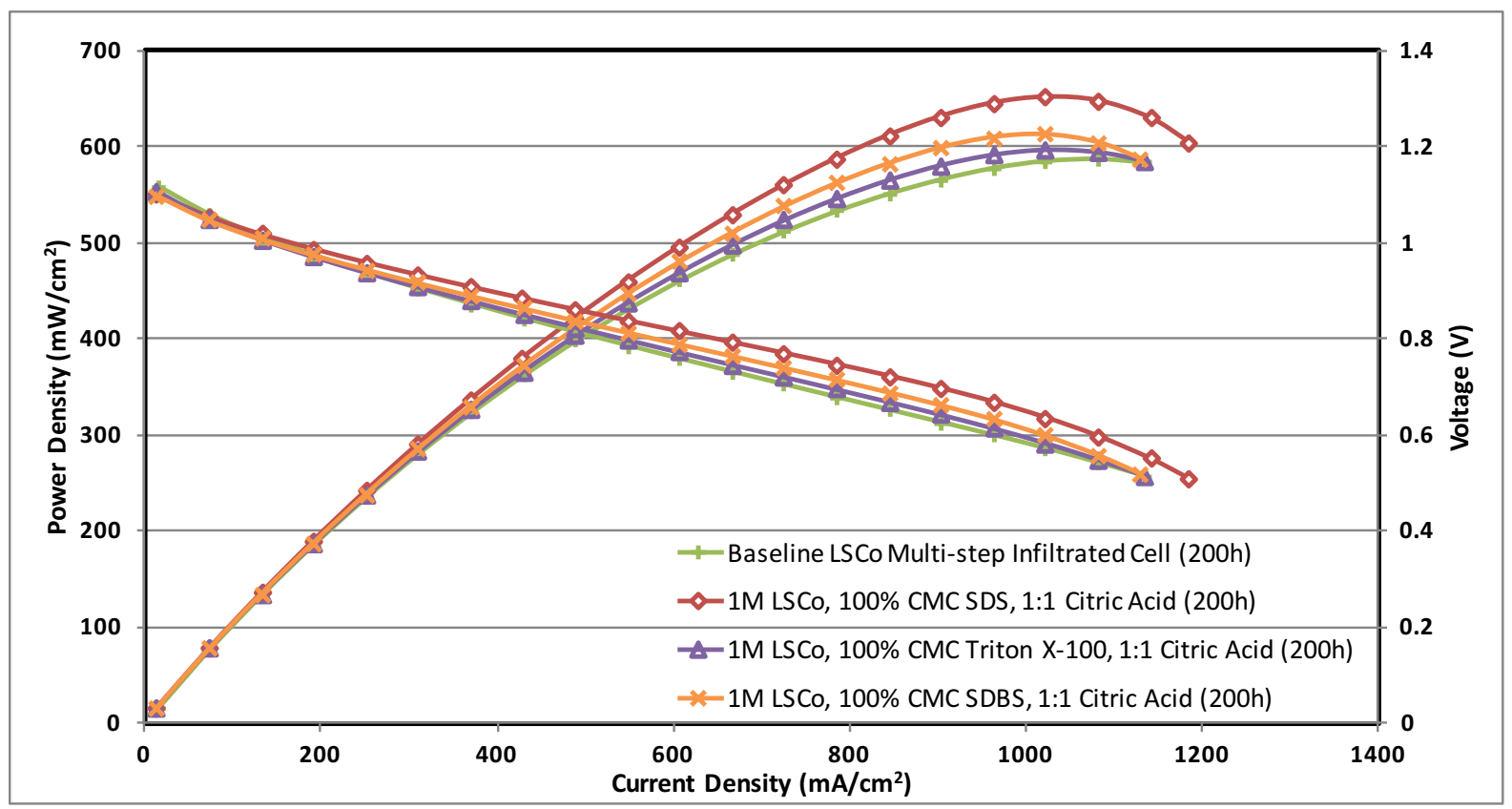

Figure 8: Polarization and Power Curves of Single-Step Infiltrated Cells versus Multi-Step Baseline Cell at 200 hours of Operation 


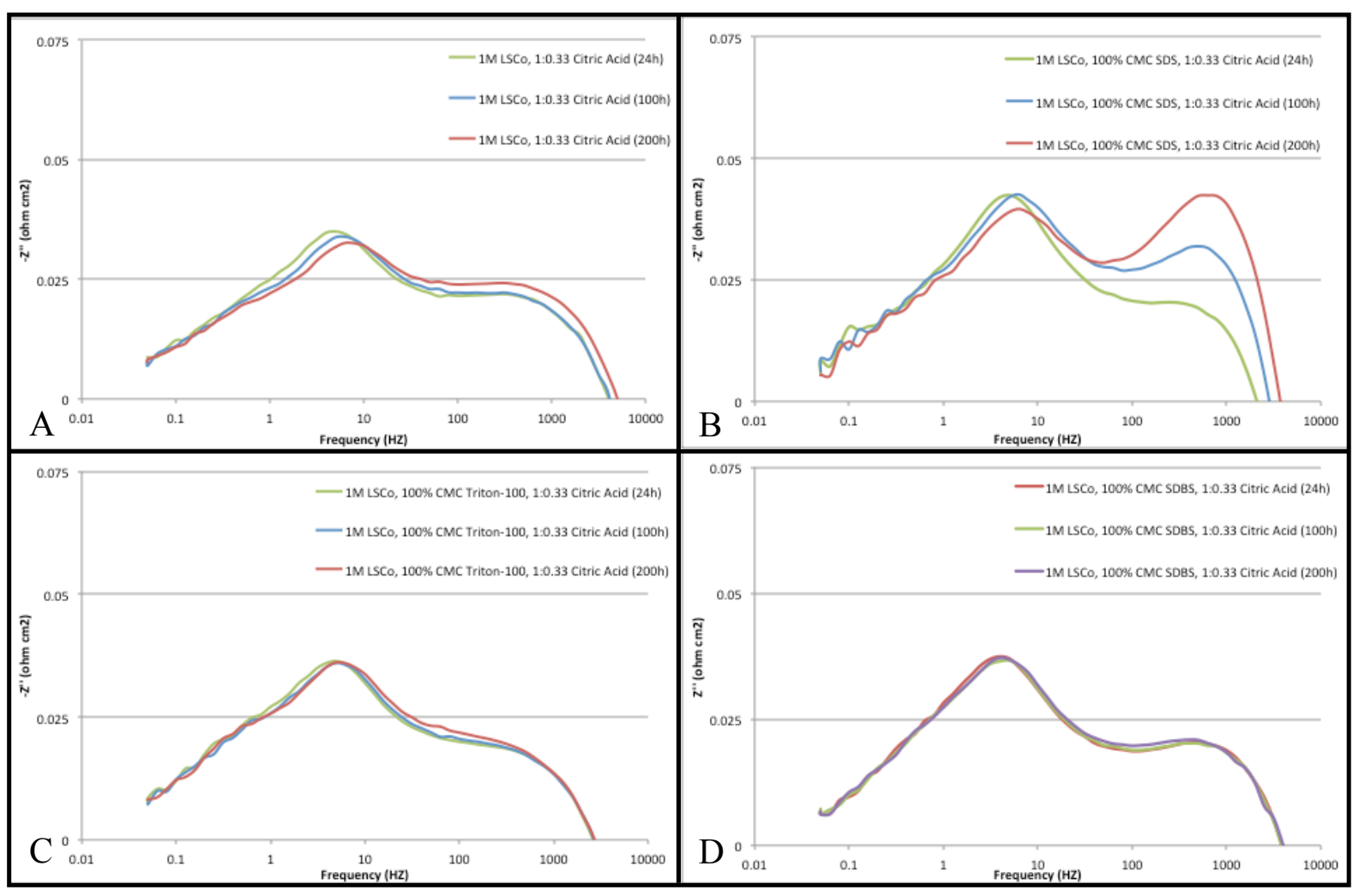

Figure 9: Impedance Analysis for 1M LSCo with 1:0.33 Citric Acid and (A) No Surfactant, (B) 100\% CMC SDS, (C) 100\% CMC Triton X-100, (D) 100\% CMC SDBS Infiltrated Cells 


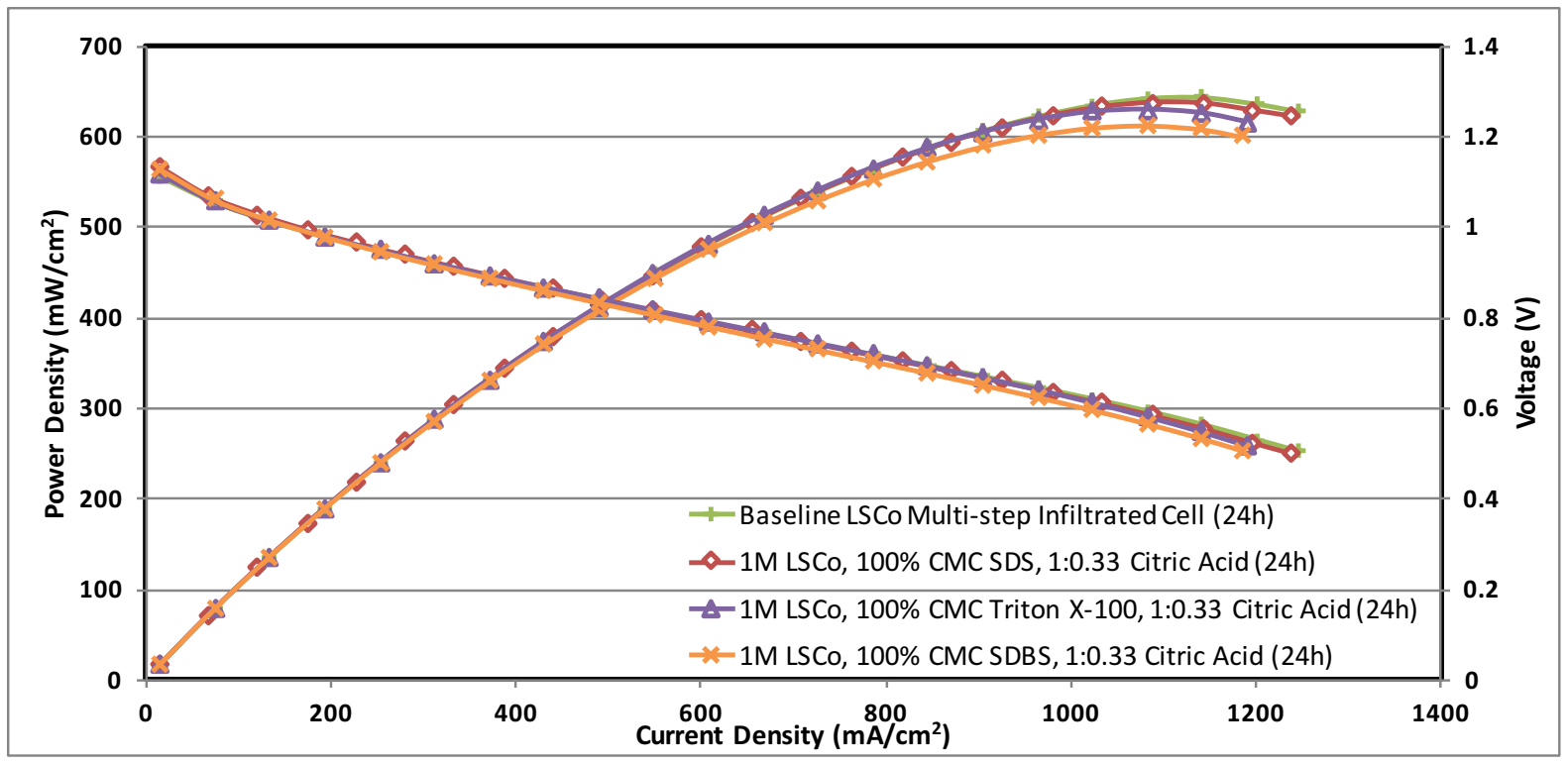

Figure 10: Polarization and Power Curves of Single-Step Infiltrated Cells versus Baseline Multi-Step Cell at BOL 


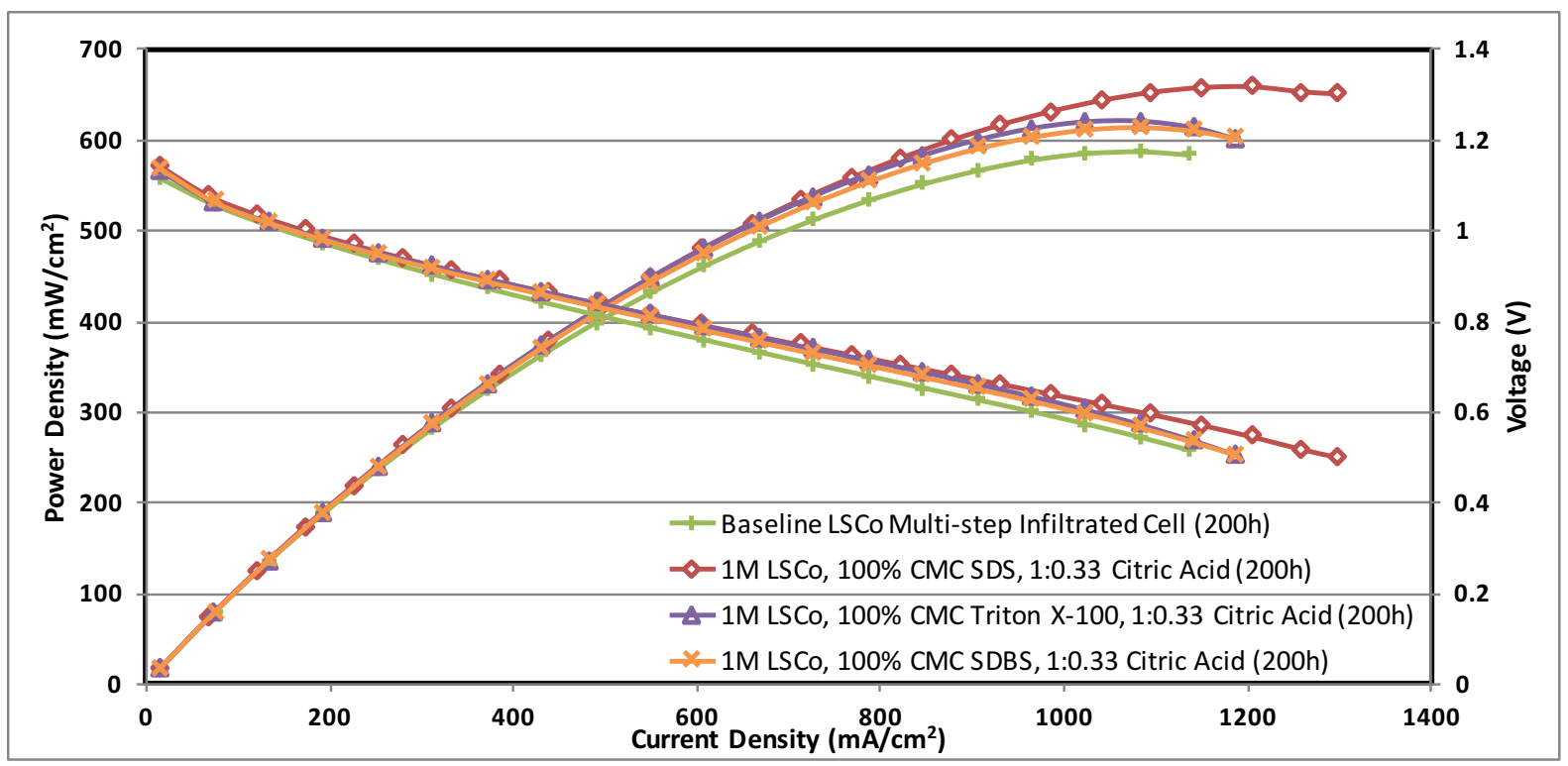

Figure 11: Polarization and Power Curves of Single-Step Infiltrated Cells versus Multi-Step Baseline Cell at 200 hours of Operation 